\title{
FEDERALISM SYMPOSIUM
}

\section{Improving Federalism: Drivers of Change, Repair Options and Reform Scenarios}

\author{
John Wanna \\ The Australian National University and Griffith University
}

\begin{abstract}
The Academy of Social Sciences in Australia (ASSA) and the Institute of Public Administration Australia (IPAA) hosted a 'Policy Roundtable on Federalism' on the 17-18 May 2007 at the University of Canberra. Around 50 attended the roundtable comprising politicians, Commonwealth and state public servants, and academics. The roundtable was provided with a number of background papers including the Hollander-Patapan article and another produced by staff of the Commonwealth Grants Commission entitled 'Trends in Commonwealth-State Financial Relations: a Grants Commission Perspective'. The roundtable focused not only on issues and challenges but, more practically, on options and how to make federalism work better.
\end{abstract}

Key words: federalism, Commonwealth-state relations, reform

\section{Pragmatism and Principles}

Examining the question of how to improve Commonwealth-state relations involved the ASSA/IPAA Roundtable focusing initially on delineating the factors shaping Australian federalism, and then exploring options for reform. Discussion often contrasted developments based on principle with more pragmatic responses to particular circumstances. Each side of the argument found its own adherents.

Advocates of the pragmatic approach - like the authors of the background article - stressed the opportunistic character of federal politicking, dealing with the preponderance of marginal issues, constructing band-aids, tortuous negotiations, fed by disingenuous inducements and mutual backsliding. Rhetoric about collaboration and cooperation was interpreted as code for centralisation or partisan agendas. One politician characterised federalism as a tactical war in which 'the states were essentially arguing for bribes' and the Commonwealth was complicit in compliance. This was considered normal in the realpolitick world of the pragmatists. Dealing with policy challenges and improving ser- vices required acceptance of this reality and a focus on practical problem solving.

Whatever the merits of pragmatism it remained highly desirable to others that federal matters should be guided by discernible principles. If the Constitution was silent on today's pressing policy domains, then other robust principles should be adopted and used sensibly to inform leaders in the nine jurisdictions about how federalism could work better. Such principles might include the degree to which problems or proposals are genuinely national in scope, promote national markets, enhance structural efficiency, or meet principles of subsidiarity and accountability. The test of these principles is not only government exhortation, but relevance to the point of view of the enduser - the citizen, client or customer, or from the transaction costs of doing business. To this group, the world would always be messy but not necessarily as messy as at present.

Debates about pragmatism versus principles raised two further dilemmas. First, if federalism was fundamentally about containing governments (as some of the literature suggests), then how can we frame our deliberations about 
how best to make it work while remaining faithful to the ideas of federalism - there is a clash between the containment of government ambitions and assisting governments to prevail. Secondly, given international pressures and the relatively small size of the Australian population, should Australia remain a federal nation or move to a more unitary structure? This cut to the heart of the matter - was federalism a nuisance or a good idea? And should we remain federal?

\section{The Death of Federalism - Real or Exaggerated?}

Some commentators contended that, internationally, federalism was in decline and languishing everywhere except in older centralist unitary nations that had recently allowed a measure of local autonomy to sub-national units. Federalism seemed to be succeeding in nations that were traditionally unitary, but were allowing some devolution to regional bodies (such as Scotland in the UK and Catalonia in Spain) to preserve the unitary state. Such devolution did not imply federalism was resurgent.

In the older and larger federations, federalism did not appear to be robust but in gradual long-term decline. Centralisation was a persistent feature of their polities, and greater attention to national and international issues also tended to undermine the premise of federal diversity. Markets were increasingly national and global, and local or regional identity was also diminishing in the face of the impact of modern communications and media. The sub-national jurisdictions risked becoming agent providers to centralising national governments.

These forces were not the only ones driving centralisation. If once it seemed that jurisdictions could be separate and coordinated, today national and international pressures mean that much more activity takes place within federal nations involving all three levels of government. Policy imperatives and the percolation of policy ideas through the system mean that there is often far more interaction and dynamism than once thought possible or desirable. Hyper-interaction characterised the relations in many policy areas such as health, education, security or infrastructure. Federalism is never static; it is characterised by a continuous process of reinvention; the operational dynamics are marked by considerable fluidity. Federalism appears a different ball game today.

The perceived decline of federalism had direct application to Australia - and perhaps the country was even leading the trend because of the weakness of countervailing forces. Australia has the most fiscally centralised system; it is one of the most homogeneous and equal federations; it has the greatest degree of concurrent powers across levels of government; and few institutional barriers stand in the way of centralisation. Distance had protected the states in the past - but new technologies and communications had eroded this physical protection. Moreover, there are no cultural regions of different ethnic groups with different languages and cultures as other federations possess. In Australia, all three levels of government-Commonwealth, state/territory and local - tended to see federalism as a malaise, not a source of effective government.

Some argued that, nonetheless, federalism and responsible government interacted in ways that could benefit good government. Federalism not only gave us separate if often blurred responsibilities, it also brought competitive governments anxious to fill policy gaps, counteract the limitations of others and compete for policy space. Multiple governments could also add to the overall accountability of the system because 'sovereign' governments were generally the best critics of other governments. They had their own experts and were resourced to undertake analysis and critique rival proposals. Rival governments were better placed to hold their competitors to account for their decisions or non-decisions than were the respective oppositions of these governments who themselves were usually under-resourced and at some distance from the policy process. Some argued that on contentious policy issues - water, climate change, congestion, infrastructural planning the existence of multiple stakeholder governments was the active accountability process in Australia. 


\section{Where to Start the Repair}

Repair options varied from investing more effort in specific policy fields to remoulding the overall architecture of federalism (especially central coordinating mechanisms and agendasetting bodies). Policy initiatives might include individual agreements about shared responsibilities or attempts to reshape the policy process to produce better alignments of policy or administrative activity. Improving the generic architecture might involve enhancing the Council of Australian Governments (COAG), establishing a joint Commonwealth-state secretariat, coordinating ministerial council agendas and agreements, encouraging the input of state officials in national agendas, and re-conceptualising the role of the Senate (especially in relation to representing state perspectives).

Most participants in the roundtable believed that the system could be gradually improved they differed largely in the extent to which they thought this possible. Reform scenarios in one area would not necessarily be suitable or applicable in another. It was a case of 'horses for courses' - examining the political, policy and administrative dynamics of an area to explore the possibilities for practical reform initiatives. They were doubtful that anyone could remake the whole system, either now or in the future, but they were nonetheless convinced that parts of the federation could be made to work much better. Repair was needed but we had to proceed from where we are at present, an obvious if oft-forgotten point. There was little purpose in devising elaborate schemes of reform only to find nothing happened or that it was too difficult politically to secure agreement and cooperation. Hence, the appeal of a new doctrine of 'strategic pragmatism' - practical steps to improve relations in selected fields based on longer-term assessments of what we preferred to see achieved. This also meant that personalities and political commitment were important ingredients in the success of reform initiatives. In light of this observation, many participants questioned why so few federal and state political leaders tended to prioritise the improvement of federal relations. History suggested few were prepared to play a pro-active role in nurturing agendas or brokering deals.

The venerable chestnut of the need for greater clarity of government functions, roles and responsibilities was raised by many participants. They pleaded in particular for the specification of policy responsibilities between the jurisdictions - and for this to be locked in place over time to allow the various participants to specialise in their business and coordinate their integration better. This was the 'holy grail' of the legal-rationalists and administrative rationalists. The former were interested in jurisdictional clarity, while the latter wanted to know for what they were responsible and leave to others what they were committed to deliver.

Many thought the prospects were good for visionary politicians and officials to agree on a clearer division of responsibilities that would enable more effective implementation subsequently. A reliance on cooperation and collaboration when almost all responsibilities are shared might be slow and inefficient and might not deliver effective or responsive services. Although such pleas were made several times - from the opening addresses to the concluding comments - the validity of the underlying assumptions was never put to the test. Does greater clarity of roles and responsibilities lead to improved outcomes, more seamless services for citizens, and greater accountability? Evidence was scant either way - but there certainly were those who believed that the world was inevitably messy and constantly evolving. Federalism could resemble a kaleidoscope of changing functions and integrations. It appeared the jury was still out on whether it was a worthwhile goal to have a strict demarcation of roles and responsibilities between the jurisdictions.

Contrary to the rationalistic logic was actual track record of political expediency characterising Commonwealth-state relations in recent decades. While governments could make occasional impassioned arguments to rationalise roles and responsibilities (or the need for shared objectives and collaborative relations), they were not about behaving in ways contrary to this logic when it suited them. Commonwealth assurances rang hollow when federal ministers decided they ought to be running schools 
or funding parents and community initiatives, setting educational curricula, micro-managing rivers, fixing roads and accident blackspots, preserving endangered parrots or interfering in planning decisions. States complain about Commonwealth forays into areas they regarded as their areas of responsibility - examples include such matters as Commonwealth-funded technical colleges, river management, direct funding of local governments for Commonwealth initiatives, regional grants, or heritage trust funds. The Commonwealth can intervene here simply because it has substantial financial resource.

While the states can attempt to take the initiative and 'push the Commonwealth' (as they did over mutual recognition of qualifications or over a carbon trading scheme) they are limited as to what resources they can expend on such proposals and how to make these initiatives truly national in character. Commonwealth initiatives often antagonise the states because they are often announced without consultation or because there is a view from Canberra that the Commonwealth knows best - they are 'their' schemes and 'their' programs and the states feel they have little choice but to comply. However, dictates from Canberra failed to recognise that the states had substantial areas of expertise and experience.

\section{Specific Reform Suggestions}

Suggestions for specific reform were forthcoming from participants with many concerning issues of procedure and process (the forum was not focused on policy suggestions in particular sectoral areas). Participants made the following suggestions:

1. Coordinate the activities of ministerial councils - especially in relation to national agendas, whole-of-government concerns and longer-term strategies;

2. Provide COAG with a joint Commonwealth-state permanent secretariat (perhaps allied to the Grants Commission or Productivity Commission) to advise on policy reforms, monitor projects and/or provide progress reports on agreed initiatives;

3. COAG's prospective agenda should include a longer-term and strategic menu. Future national issues could be identified by a process whereby they are of significant national importance, joint involvement was necessary, and there was significant community benefit; the new Reform Council could assist in this process if it were to play a strategic agenda-setting role for all three levels of government;

4. Rationalise the 90 or so specific purpose payment schemes, comprising in total some $\$ 23$ billion, to standardise their terms, conditions and requirements, and focus more on outcomes than inputs;

5. In general terms, allow the Commonwealth to focus on national issues, single markets, its own constitutional powers and redistributive policies, and allow the states to focus on areas of service delivery (reducing the Commonwealth's role here);

6. In areas of shared responsibilities, the Commonwealth and states should agree the broad parameters of their separate roles (eg the Commonwealth focusing on national highways, the states on state and regional roads; the Commonwealth on the larger river systems and rural water and the states on urban water; the Commonwealth on national infrastructure and the states on 'place management' including urban and regional planning);

7. Renew micro-economic agendas including the rationalisation of regulations, further harmonisation of standards and regulations (uniformity may be preferable even if such regulation is not perfect); the extension of mutual recognition regimes to the professions and professional services;

8. COAG ought to encourage states to devolve and decentralise responsibilities within the states themselves (to regions and local government areas). They often made general arguments about the benefits of devolution but did not consider 
these arguments applied to their own state responsibilities;

9. Reduce the duplicate administrative structures that had arisen between the Commonwealth and state jurisdictions the proliferation of parallel or similar departments;

10. Provide the states with some guaranteed revenue share to fund their responsibilities (the GST goes part-way in this direction); and

11. Use the community and private sector for ideas - move away from 'governments know best' to bring wider perspectives and alternative viewpoints.
The roundtable concluded with a prediction that during the next 20 years fiscal issues would become more rather than less important, that national issues would tend to gravitate to the Commonwealth level while regional and delivery issues would gravitate down to the states. Education and community services (and possibly health) were considered by many as the most likely to be driven by devolved forces, while infrastructure, energy and environmental issues may tend the other way. There was a widespread consensus that greater levels of trust would be needed to make federalism work better and provide enhanced policy outcomes for the Australian community. 